\title{
VAT and electronic commerce: the new rules as a means for simplification, combatting fraud and creating a more level playing field?
}

\author{
Marta Papis-Almansa ${ }^{1}$
}

Published online: 4 September 2019

(C) The Author(s) 2019

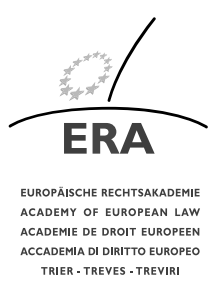

Abstract Removing obstacles to e-commerce in the Single Market and ensuring effective taxation in the context of the digital economy has been high on the political agenda both in the European Union and beyond. Recently the VAT rules on crossborder e-commerce have gone through a thorough modernisation with a package of new provisions in the EU VAT legislation coming into effect as of 2019 and 2021. Further measures with the objective of laying down solid foundations for an effective, fair, simple and fraud-resistant taxation of e-commerce transactions have been envisaged. This article helps to navigate a complex set of new provisions and offers reflections on whether the new rules will achieve their objective.

Keywords European VAT · Value added tax · E-commerce · Cross-border supplies · Digital economy $\cdot$ Platforms

\section{Introduction}

The taxation of electronic commerce (e-commerce $)^{1}$ has been attracting the attention of policymakers, tax administrations and academics for at least the last thirty years.

\footnotetext{
${ }^{1}$ As an element of a broader concept of a "digital economy". For the definition of this, its characteristics, importance for the economy and the challenges involved for taxation, see for instance European Commission, Report of the Commission Expert Group on Taxation of the Digital Economy from 28.5.2014 available at https://ec.europa.eu/taxation_customs/sites/taxation/files/resources/documents/ taxation/gen_info/good_governance_matters/digital/report_digital_economy.pdf [5].
}

This article is based on a presentation given by the author at the Annual Conference on European VAT Law 2018, organised by ERA in Trier, Germany on 22-23 November 2018.

M. Papis-Almansa

marta.papis-almansa@har.lu.se

1 Senior Lecturer, Lund University, Lund, Sweden 
The emergence and rapid development of e-commerce has created the challenges of creating a sound legal environment for online transactions and their effective VAT treatment. The internet has made it possible to purchase goods and services without the typical geographical and time constraints characteristic of traditional stationary trade and left the existing rules of the VAT Directive ${ }^{2}$ insufficient to assess when, how much and where VAT should be collected and how to ensure that it is effectively collected. The role of VAT in ensuring appropriate tax revenue accrual from e-commerce businesses, and the need to adjust the rules on VAT to the challenges of e-commerce in order to create a level playing field for economic operators have been recognised and discussed in the context of the EU and the OECD since the 1990s. ${ }^{3}$ The rapid and continuing development in the digitalisation of the global economy has put the taxation of e-commerce in the spotlight again in recent years. ${ }^{4}$ The existing problems of ensuring fair taxation of cross-border e-commerce, lowering compliance costs for businesses and protecting national tax revenues have become even more vexing.

Removing obstacles to e-commerce in the Single Market was one of the four pillars of the Action Plan on VAT presented by the European Commission on 7 April 2016. ${ }^{5}$ As a means of realisation of that goal, and as a part of the Digital Single Market Strategy, on 5 December 2017 the so-called "e-commerce VAT package"6 was adopted with new rules taking effect in part as of from 1 January 2019 and partly from 1 January 2021. On 11 December 2018, the Commission proposed further clarifying and implementing provisions ${ }^{7}$ to be included both in the VAT Directive and

${ }^{2}$ Council Directive 2006/112/EC of 28 November 2006 on the common system of value added tax [2006] OJ L 347/1.

${ }^{3}$ Raponi, O' Sullivan [19], p. 12. The discussions in the framework of OECD resulted in adoption of a set of recommendations incorporated in the so-called 1998 "Ottawa Taxation Framework Conditions", available at https://www.oecd.org/ctp/consumption/1923256.pdf [16].

${ }^{4}$ The tax challenges of the digital economy have been a crucial part of the OECD/G20 Base Erosion and Profit Shifting Project, addressed in 2015 BEPS Action 1 Report (OECD, Addressing the Tax Challenges of the Digital Economy, Action 1-2015 Final Report, available at http://www.oecd.org/tax/addressingthe-tax-challenges-of-the-digital-economy-action-1-2015-final-report-9789264241046-en.htm [17]).

${ }^{5}$ European Commission, Communication from the Commission to the European Parliament, the Council and the European Economic and Social Committee on an action plan on VAT. Towards a single EU VAT area-Time to decide, $\operatorname{COM}(2016) 148$.

${ }^{6}$ The e-commerce VAT package as such consist of Council Directive (EU) 2017/2455 of 5 December 2017 amending Directive 2006/112/EC and Directive 2009/132/EC as regards certain value added tax obligations for supplies of services and distance sales of goods [2017] OJ L 348/7, Council Implementing Regulation (EU) 2017/2459 of 5 December 2017 amending Implementing Regulation (EU) No. 282/2011 laying down implementing measures for Directive 2006/112/EC on the common system of value added tax, [2017] OJ L348/32 and Council Regulation (EU) 2017/2454 of 5 December 2017 amending Regulation (EU) No. 904/2010 on administrative cooperation and combating fraud in the field of value added tax.

${ }^{7}$ European Commission, Proposal for a Council Directive amending Council Directive 2006/112/EC of 28 November 2006 as regards provisions relating to distance sales of goods and certain domestic supplies of goods, from 11 December 2018, COM(2018) 819 final and Proposal for a Council Implementing Regulation amending Implementing Regulation (EU) No. 282/2011 as regards supplies of goods or services facilitated by electronic interfaces and the special schemes for taxable persons supplying services to non-taxable persons, making distance sales of goods and certain domestic supplies of goods, from 11 December 2018, COM(2018) 821 final. 
in the VAT Implementing Regulation. ${ }^{8}$ The purpose of the new rules, as announced by the Commission, has been to level the playing field between traditional commerce and e-commerce, eliminate the distortions that currently exist in favour of non-EU businesses, reduce compliance costs and the complexity of VAT obligations for business, and minimise the risk of VAT fraud and non-compliance leading to VAT revenue losses. ${ }^{9}$

The purpose of this paper is to outline the major changes and the new rules introduced by the E-Commerce Directive 2017/2455 and Council Implementing Regulation $2017 / 2459^{10}$ and further, the follow up measures, which have been proposed by the Commission. These new rules and measures will be further commented on both in terms of the conceptual and interpretative challenges that they bring about, as well as their practical consequences. The goal is to answer the question of whether the intended purpose of the new rules as to simplification, fraud resistance and a more level playing field has been achieved and what the remaining issues are which should be addressed. ${ }^{11}$

\section{Background and rationale}

The modernisation and adjustment of the rules of the VAT Directive to e-commerce have been a gradual process in the EU, with the first specific rules for radio and television broadcasting services and certain electronically-supplied services being adopted as early as in 2002 and taking effect in $2003 .{ }^{12}$ With the introduction of the taxation of such services in the Member State of consumption, where provided by a supplier located outside the EU, ${ }^{13}$ EU legislation took the first step in the process of aligning the treatment of e-services with the OECD 1998 Ottawa Framework.

\footnotetext{
${ }^{8}$ Council Implementing Regulation (EU) No. 282/2011 of 15 March 2011 laying down implementing measures for Directive 2006/112/EC on the common system of value added tax, [2011] OJ L 77/1.

${ }^{9}$ See European Commission, Proposal for a Council Directive amending Directive 2006/112/EC and Directive 2009/132/EC as regards certain value added tax obligations for supplies of services and distance sales of goods COM(2016) 757 final COM (2016) 757 final, p. 2 VAT losses in the EU were estimated by the Commission as amounting to 5 billion annually (Ibid.).

${ }^{10}$ The changes to the provisions on administrative administration introduced by Council Regulation (EU) 2017/2454 and regarding the exchange and storage of information by Member States and related to the extension of MOSS are not further discussed in this article. For a comprehensive presentation of the amendments see Terra [21].

${ }^{11}$ It should be added that besides the e-commerce VAT package, other related amendments to the VAT Directive include those introduced by Council Directive (EU) 2018/1713 of 6 November 2018 amending Directive 2006/112/EC as regards rates of value added tax applied to books, newspapers and periodicals, [2018] OJ L 286/20 enabling Member States to apply reduced rates to electronically supplied publications.

${ }^{12}$ Council Directive 2002/38/EC of 7 May 2002 amending and amending temporarily Directive $77 / 388 / \mathrm{EEC}$ as regards value added tax arrangements applicable to radio and television broadcasting services and certain electronically supplied services, [2002] OJ L 128, p. 41-44. For a more detailed historical background, see Herbain [9].

${ }^{13}$ With a special scheme allowing non-established taxable persons to register and account for VAT in a single Member State for their supplies in all Member States.
} 
The next step came with the 2008 VAT Package amendments ${ }^{14}$ which addressed intra-EU distortions of competition between providers of e-services established in different Member States, by changing the place of supply rules for B2C telecommunication, broadcasting and electronically supplied services (TBE services). Since 1 January 2015, such services have been taxed at the place where the consumer is located, thus at their destination, rather than at their origin, departing from the general B2C rule for the supply of services laid down in Article 45 of the VAT Directive. These new rules were also accompanied by the introduction of a Mini One Stop Shop (MOSS) for the suppliers, to register, declare and pay VAT via a web portal in a single Member State. Additional guidance and support regarding, inter alia, the identification and location of the customer has been provided in the provisions of the VAT Implementing Regulation and (non-binding) explanatory notes issued by the Commission. ${ }^{15}$

Even before the provisions on the B2C TBE services entered into force, in its 2014 report, ${ }^{16}$ the Commission Expert Group on Taxation of the Digital Economy acknowledged that further steps would need to be taken. Priority goals recognised in the report included broadening One-Stop-Shop, which should be available for all B2C supplies of goods and services as a means of lowering administrative costs and the compliance burden for small and medium size enterprises. Furthermore, the report stressed the need to address distortions of competition and the lack of neutrality in the treatment of the supply of goods of small value, the importation of which is exempt from VAT. The so called "small consignment exemption" applies to imported goods, the value of which does not exceed the threshold of EUR 10 to 22 as determined by individual Member States. The ground for the next round of changes has been prepared.

In the meantime, e-commerce in Europe has been maturing and further expanding, with a significant growth in cross-border e-commerce. ${ }^{17}$ The 2017 e-commerce VAT package was indeed the planned next step which besides the earlier recognised priorities, addressed also other issues, such as the complexity of VAT obligations also those stemming from the provisions regarding TBE services in force since 2015. According to the Commission, there are three main reasons to act. The first one is the high com-

\footnotetext{
${ }^{14}$ The core of which constitutes Council Directive 2008/8/EC of 12 February 2008, amending Directive 2006/112/EC as regards the place of supply of services [2008] OJ L 44/11. See also Council Implementing Regulation (EU) No. 1042/2013 of 7 October 2013 Amending Implementing Regulation (EU) No. 282/2011 as Regards the Place of Supply of Services [2013] OJ L 284/1.

${ }^{15}$ Explanatory notes on the EU VAT changes to the place of supply of telecommunications, broadcasting and electronic services that entered into force in 2015, published 3.04.2014, available at https://ec.europa. eu/taxation_customs/sites/taxation/files/resources/documents/taxation/vat/how_vat_works/telecom/ explanatory_notes_2015_en.pdf.

${ }^{16}$ European Commission, Report of the Commission Expert Group on Taxation of the Digital Economy from 28.5.2014 [5].

${ }^{17}$ In accordance with the statistics presented by the European Commission, Online sales in the EU are worth EUR 550 billion a year, EUR 96 billion of which comes from cross-border online sales. See European Commission, VAT for online businesses factsheet, available at: https://ec.europa.eu/ taxation_customs/sites/taxation/files/vat-e-commerce-factsheet.pdf [6]. See also Ecommerce Europe, European Ecommerce Report 2018 available at https://www.ecommerce-europe.eu/research/ecommerceeurope-reports/ [3].
} 
pliance costs for businesses ${ }^{18}$ which follow from the complexity of VAT obligations. Secondly, the lack of neutrality leads to distortions of competition between EU and no-EU businesses as a consequence, on the one hand, of more favourable rules for no-EU businesses and, on the other, their non-compliance. Finally, Member States have been losing valuable tax revenues ${ }^{19}$ as a result of the complexity of the existing system and the small consignment exemption. ${ }^{20}$

\section{The new rules in a nutshell}

\subsection{Three categories of transactions impacted}

The measures and amendments introduced by the 2017 e-commerce VAT package can be divided into three main categories, based on the type of transactions these changes relate to. First of all, the provisions relating to B2C TBE services have been modified. The second group of amendments concerns intra-Community distance sales of goods while the third category consist of new rules for B2C importation, which as of from 2021 will coincide with a new concept of "distance sales of goods imported from third territories or third countries" as regards some of the transactions. The main changes within those categories will be outlined below in Sects. 3.2-3.4. The new rules on electronic interfaces facilitating distance sales, which concern both intra-Community distance sales of goods, and distance sales of goods imported from third territories or third countries, will be discussed separately in Sect. 4 .

\subsection{B2C Telecommunication, broadcasting and electronically supplied services: simplifications for businesses}

The first category of new rules, which have been in force from 1 January 2019, address the compliance burden for businesses supplying e-services to customers in the EU, which has increased in complexity since 1 January 2015, despite the availability of MOSS. The difficulties lie, inter alia, in the necessity for businesses supplying to non-taxable customers to establish where the customer is located, ${ }^{21}$ which has proved to be especially burdensome for micro- and small businesses. What is more, these businesses, while possibly falling under the domestic exemption threshold, may be required to charge VAT and to comply with related obligations as determined by laws of the Member State of the customer's location. ${ }^{22}$

\footnotetext{
${ }^{18}$ Estimated as EUR 8000 annually for each Member State which a business supplies to.

${ }^{19}$ The Commission estimated the losses at EUR 5 billion annually, out of which 1 billion is due to the exemption and 4 billion is a consequence of non-compliance and abuse.

${ }^{20} \mathrm{COM}(2016) 757$ final, p. 2.

${ }^{21}$ The other difficulty is the necessity to identify the customer's taxable or non-taxable status of, which in case of e-services is even more complex than in the case of other services. Customer identification was not addressed in the 2017 e-commerce VAT package. See Lamensch [12], p. 39 and Lamensch, Adoption of the E-Commerce VAT Package ... [10].

${ }^{22}$ European Commission, Commission Staff Working Document, Impact Assessment Accompanying the document Proposals for a Council Directive, a Council Implementing Regulation and a Council Regulation on Modernising VAT for cross-border B2C e-Commerce, SWD(2016) 379 final, Brussels, 1.12.2016, Sect. 2.3.3.
} 
As a measure alleviating the problem, the new rules introduce a threshold of EUR $10000^{23}$ of the total value, exclusive of VAT, of cross-border B2C TBE services, below which the special rule as to the place of supply, of Article 58 of the VAT Directive is not applicable. ${ }^{24}$ Where the value of such services supplied by a business does not exceed the threshold in the current calendar year and in the course of the preceding calendar year, ${ }^{25}$ the place of supply of such services is determined based on the general rule laid down in Article 45 of the VAT Directive, pursuant to which the place of supply of services to a non-taxable person shall be the place where the supplier has established his business. ${ }^{26}$ The simplification is not compulsory for businesses, who can opt for taxation in the Member State of location of the customer. ${ }^{27}$ Importantly, the simplification is not available for non-EU businesses, and business that are established in more than one Member State. ${ }^{28}$

Easing compliance burden for businesses is one of the core objectives of the new rules. The measure chosen does compromise the OECD-endorsed principle of taxation in the country of consumption, recognised in the EU as a principle that ideally would apply to all supplies of services. ${ }^{29}$ Compliance with that principle together with removal of distortions and revenue loss, was one of the objectives pursued by the rules on the place of supply for B2C TBE services which have been in force since 2015. Nevertheless, taxation at destination of B2C supplies has been made conditional upon the absence of any disproportionate administrative burden for businesses. ${ }^{30}$ Taking a step back and returning to taxation at origin as of a share of those services indicates that the changes introduced in 2015 were too ambitious and onerous for micro-businesses, with MOSS being an insufficient tool to alleviate the administrative burden. Introduction of a threshold is indeed a major compensation for business, which can account for and declare VAT in their home Member State, in accordance with the national rules.

Since the threshold is determined based on the value of turnover of a particular type of services (cross-border B2C TBE services), ${ }^{31}$ not only micro-and small businesses, but also businesses, whose domestic turnover or turnover from other cross-

${ }^{23}$ Or the equivalent in national currency.

${ }^{24}$ Article 58(2)(c) of the VAT Directive.

${ }^{25}$ Ibid.

${ }^{26}$ The Commission has estimated that as a result of the amendment approximately 6500 businesses declaring VAT through MOSS until 1 January 2019, will not need to use the special scheme any more.

${ }^{27}$ Article $58(4)$ of the VAT Directive.

${ }^{28}$ Article 58(2)(a) of the VAT Directive.

${ }^{29}$ See Council Directive 2008/8/EC of 12 February 2008 amending Directive 2006/112/EC as regards the place of supply of services, para. 3 of Preamble. See also European Commission, Commission Staff Working Document, Impact Assessment, Accompanying the document Proposals for a Council Directive, a Council Implementing Regulation and a Council Regulation on Modernising VAT for cross-border B2C e-Commerce, $\operatorname{SWD}(2016) 379$ final, p. 9.

${ }^{30}$ See Council Directive 2008/8/EC of 12 February 2008 amending Directive 2006/112/EC as regards the place of supply of services, para. 6 of Preamble.

${ }^{31}$ As of from 1 January 2021, the same threshold will apply to businesses making distance sales of goods and supplies of TBE services and the value of services from both the categories will be taken into account for the purposes of the threshold. See the new Article 59c of the VAT Directive, discussed further in Sect. 3.3. 
border transactions is above EUR 10000 , may avail themselves of that provision. Thus, the proportionality of the new rule should be questioned, as it seems to go further than necessary to achieve the purpose of lowering compliance cost for microbusinesses.

The new Article 58(2) of the VAT Directive introduces different treatment between businesses established in one Member State on one hand, and those either not established in the EU at all, or established in two or more Member States on the other. In other words, the new rule discriminates between EU and non-EU businesses ${ }^{32}$ and could potentially infringe freedom of establishment of EU businesses, which do not benefit from the threshold if they are established in more than one Member State.

The second simplification for businesses supplying TBE services to final consumers is a decrease in the number of pieces of evidence that a supplier has to collect to apply one of the presumptions regarding the location of the customer for the purposes of establishing the place of supply. In principle, in the circumstances laid down in Article $24 \mathrm{~b}(\mathrm{~d})$ of the VAT Implementing Regulation, ${ }^{33}$ the location of a customer is presumed to be a place identified as such by the supplier based on two items of non-contradictory evidence as listed in Article 24f of the VAT Implementing Regulation. ${ }^{34}$ From 1 January 2019, Article 24 b of the VAT Implementing Regulation envisages an exception allowing businesses to rely on one item of evidence where the total value of the supplies of the B2C TBE services, exclusive of VAT does not exceed EUR $100000,{ }^{35}$ in the current and the preceding calendar year. ${ }^{36}$ Furthermore, the condition for the application of that exception is that the services are supplied from a business establishment or a fixed establishment located in a Member State. The simplification is therefore not available for non- EU businesses, discriminating against the latter in a similar vein to the EUR 10000 threshold, commented on above.

Finally, the other changes in effect from 1 January 2019, addressing administrative burdens and facilitating the use of MOSS include an amendment to Article 219a and Article 358a of the VAT Directive. In accordance with the new wording of Article $219 \mathrm{a}(2)(\mathrm{b}),{ }^{37}$ the invoicing rules of the Member State of identification, instead of the invoicing rules of the Member States to which supplies are made, are applicable where MOSS is used. Article 358a(1), in its new wording, extends the possibility of the use of MOSS by businesses not established in the European Union (the nonUnion scheme) who are required to be identified for VAT purposes in the European

\footnotetext{
${ }^{32}$ Lamensch, Adoption of the E-Commerce VAT Package ... [10], p. 189.

${ }^{33}$ Thus in circumstances other than those covered by Article 24a and Article 24b(a), (b) and (c) of the VAT Implementing Regulation.

${ }^{34}$ The list includes items such as: the billing address of the customer, the IP address of the device used by the customer or any method of geolocation, bank details, the Mobile Country Code of the International Mobile Subscriber Identity stored on the consumer`s SIM card, the location of the customer's fixed landline or other commercially relevant information.

${ }^{35}$ Or the equivalent in national currency.

${ }^{36}$ The provision further specifies that the evidence shall be provided by a person involved in the supply of the services other than the supplier or the customer, as listed in points (a) to (e) of Article 24f of the VAT Implementing Regulation.

${ }^{37}$ See Article 1(2) of Council Directive (EU) 2017/2455.
} 
Union. ${ }^{38}$ Until 1 January 2019, neither the non-Union scheme, nor the Union scheme were available for such businesses. ${ }^{39}$

\subsection{Intra-community distance sale of goods and extension of MOSS}

In 2021 further changes introduced by the e-commerce VAT package will become effective. The focus of this section is on changes regarding supplies, which are currently referred to as "distance sales" and related changes to Mini One Stop Shop (MOSS), which, as of from 2021, due to its significant extension, will become a One Stop Shop (OSS). ${ }^{40}$

The VAT Directive, in its currently binding wording, does not include a definition of "distance sale of goods" as such. It is not a separate category of taxable transactions. ${ }^{41}$ The term is used in the context of the place of supply rules. Article 33 of the VAT Directive, provides an exception to the general rule for the place of supply of goods with transport laid down in Article 32. According to the general rule, the place of supply of goods with transport is the place where the goods are located at the time when dispatch or transport of the goods to the customer begins. However, in case of distance sales, where the conditions of Article 33 are fulfilled, the place is deemed to be the place where the goods are located at the time when dispatch or transport of the goods to the customer ends. Article 33 is generally speaking applicable to B2C transactions, or more precisely - apart from transactions carried out with non-taxable persons - with taxable persons or a non-taxable legal persons, whose intra-Community acquisitions of goods are not subject to VAT pursuant to Article 3(1) of the VAT Directive. The goods supplied cannot consist of new means of transport, or of goods supplied after assembly or installation. Furthermore, in order for a transaction to fall within the scope of Article 33 of the VAT Directive, goods have to be dispatched or transported by or on behalf of the supplier from a Member State other than that in which dispatch or transport of the goods ends.

Whether or not the place of supply rule laid down in Article 33 is applicable further depends on the total value, exclusive of VAT of distance sales to a given Member State exceeding a threshold set in that Member State in accordance with Article 34 of the VAT Directive. ${ }^{42}$ That threshold, in principle, is EUR $100000^{43}$ but Member States may limit the threshold to EUR 35000 where they fear that the higher threshold might cause serious distortion of competition. Where the threshold is not exceeded, taxable persons may nevertheless opt for taxation in accordance with Article $33 .{ }^{44}$

\footnotetext{
${ }^{38}$ For instance due to carrying out occasional transactions subject to VAT in a Member State.

${ }^{39}$ See the old definition of "taxable person not established within the Community" in Article 358 a(1) and the definition of a "taxable person not established in the Member State of consumption" in Article 369a.

${ }^{40}$ Yet, considering the number of special schemes and types of OSS which will become available from 2021 one may wonder whether the term "One Stop Shop" is still appropriate.

${ }^{41}$ Title IV of the VAT Directive distinguishes between supplies of goods, intra-Community acquisitions of goods, supply of services and importation of goods.

${ }^{42}$ Only goods which are products subject to excise duty are taxed at destination irrespective of the threshold, See Article 34(1)(a).

${ }^{43}$ Or the equivalent in national currency.

${ }^{44}$ Article 33(4).
} 
The differences in the thresholds set across the EU, and the administrative burden related to registration and payment of VAT by suppliers in all the Member States to which a supplier is transporting or dispatching goods (since MOSS is currently not available for such supplies) has been a barrier to the growth of e-commerce. Furthermore, difficulty in monitoring the thresholds has led to a significant level of non-compliance by businesses.

The new rules on distance sale of goods, consist of, first of all, definitions of this type of transaction, introduced in Article 14(4) of the VAT Directive, in title IV under the rubric "Taxable transaction". 45 The place of insertion of the definitions suggests that distance sales do in fact constitute a sub-category of supplies of goods, a special type of a taxable transaction.

The inserted definition distinguishes between "intra-Community distance sales of goods" 46 and the "distance sales of goods imported from third territories and third countries". ${ }^{47}$ The latter category, under the current rules does not qualify as a distance sale and is treated instead as the importation of goods. ${ }^{48}$ As has already been mentioned, for a transaction to fall under Article 33 of the VAT Directive, the transport has to begin in one of the Member States. The distance sale of goods imported from third territories or third countries will be further discussed in more detail in Sect. 3.4. The definition of the intra-Community distance sales of goods incorporates the conditions which are currently set in Article 33 of the VAT Directive. Additionally, the new definition clarifies that a supply falls within the scope of that category "where the supplier intervenes indirectly in the transport or dispatch of the goods." Indeed the current wording of Article 33 has caused interpretative difficulties, as it has not been straightforward when goods should be considered as "dispatched or transported by or on behalf of the supplier". The new definition codifies what was earlier agreed "almost unanimously" by the VAT Committee during the 104th meeting. ${ }^{49}$ The guidelines further specify in which circumstances the supplier should be considered as having indirectly intervened in the transport or dispatch of the goods. ${ }^{50}$ The Commission has also proposed codifying this latter clarification in the provisions of the VAT Implementing Regulation. ${ }^{51}$

Furthermore, the e-commerce VAT package has addressed current shortcomings by removing the existing thresholds applicable to distance sales of goods. Instead, as of from 2021, the EUR 10000 threshold, which between 1 January 2019 and 31

\footnotetext{
${ }^{45}$ See Article 2(1) of the Council Directive (EU) 2017/2455.

${ }^{46}$ Article 14(4)(1).

${ }^{47}$ Article 14(4)(2).

${ }^{48}$ Importation which can be followed by a distance sale of goods, where the transport of the goods ends in a Member State, other than that in which the goods are imported. See the current Article 33(2).

${ }^{49}$ VAT Committee, Guidelines resulting from the 104th meeting of 4-5 June 2015, document Ctaxud.c.1(2015)4820441-876 [22].

${ }^{50}$ Ibid. See point 2 of the guidelines.

${ }^{51}$ European Commission, Proposal for a Council Implementing Regulation, amending Implementing Regulation (EU) No. 282/2011 as regards supplies of goods or services facilitated by electronic interfaces and the special schemes for taxable persons supplying services to non-taxable persons, making distance sales of goods and certain domestic supplies of goods from 11 December 2018, COM(2018) 821 final, Article 1(1)(b), proposing to add a new Article 5a to the VAT Implementing Regulation.
} 
December 2020 is relevant for the determination of the place of supply of B2C TBE services, will be extended to distance sales of goods. ${ }^{52}$ In other words, and in accordance with Article 59c, where the total value, exclusive of VAT of both the crossborder B2C TBE services and distance sales of goods ${ }^{53}$ by a taxable person does not exceed in the current and did not exceed in the preceding calendar year EUR $10000,{ }^{54}$ these transactions will be taxed at origin, instead of at destination. ${ }^{55}$

Another facilitation available from 1 January 2021 and addressing current administrative burdens, is the extension of MOSS to the distance sale of goods ${ }^{56}$ and also to services other than TBE B2C services, where such transactions are taxed at destination. When it comes to the intra-Community distance sales of goods, only suppliers established within the European Union will be able to use the special scheme. ${ }^{57}$ Another simplification for EU suppliers using the extended scheme for intra-Community distance sale of goods is that no invoice will have to be issued for such supplies. ${ }^{58}$ The non-Union scheme will be extended to the supply of services to non-taxable persons. ${ }^{59}$ An additional special scheme for distance sales of goods imported from third territories or third countries, which is further discussed in Sect. 3.4, will be also available. ${ }^{60}$ The latter however, will not be applicable to transactions, where the transport of goods begins in one of the Member States. ${ }^{61}$

The introduction of definitions including the clarification of the scope of the concept of distance sales of goods, as well as making OSS available to suppliers of goods and services will ease compliance and reduce the costs thereof for businesses. On the

${ }^{52}$ Chapter 3a "Threshold for taxable persons making supplies of goods covered by point (a) of Article 33 and supplies of services covered by Article 58" will be inserted in Title V of the VAT Directive. See Article 2(7) of the Council Directive (EU) 2017/2455.

${ }^{53}$ Note that this can result for certain businesses supplying cross border both TBE services and goods, and falling under the threshold during period between 1 January 2019 and 31 December 2020, in exceeding that threshold as from 1 January 2021, even where the value of the TBE services which they supply is below EUR 10000.

${ }^{54}$ Or the equivalent in national currency.

${ }^{55}$ For TBE services, the place of supply will be determined based on Article 45 of the VAT Directive, where the supplier has established his business, while the place of supply of goods will be established on the basis of Article 32 of the VAT Directive, at the place where the goods are located at the time when dispatch or transport of the goods to the customer begins.

${ }^{56}$ The Commission has proposed to further amend the Union scheme by making it available also for domestic supplies of goods by platforms facilitating supplies of goods to which the new Article 14a is applicable. See COM(2018) 819 final, Article 1(6)-(11). See further Sect. 4.

${ }^{57}$ Compare Title XII, Chap. 6, new Sect. 2 "Special scheme for services supplied by taxable persons not established within the Community" with the new Sect. 3 "Special scheme for intra-Community distance sales of goods and for services supplied by taxable persons established within the Community but not in the Member State of Consumption".

${ }^{58}$ See the new wording of Article 220(2) of the VAT Directive, applicable from 1.1.2021.

${ }^{59}$ See the new wording of Article 359 introduced by Article 2(16) of the Council Directive (EU) $2017 / 2455$.

${ }^{60}$ See the new Sect. 4 "Special scheme for distance sales of goods imported from third territories or third countries" in Title XII, Chap. 6 of the VAT Directive, introduced by Article 2(30) of the Council Directive (EU) $2017 / 2455$.

${ }^{61}$ See definition in the new Article 14(4)(2) and Sect. 3.4 below. 
other hand, non-EU businesses involved in intra-Community distance sales will not fully benefit from the simplification.

The positive practical consequences for businesses do not go hand-in-hand with conceptual and systematic simplification of the provisions of the VAT Directive, which as of from 2021 will include a new type of transaction overlapping with the concept of the importation of goods ${ }^{62}$ and will encompass several OSS schemes, differing in scope as to the taxable persons and types of transactions they apply to.

Furthermore, the simplification for businesses through the chosen measures in its current form seems to be inevitably linked with an increase in the administrative burden for the Member States. ${ }^{63}$ The smooth functioning of extended OSS will require effective and actual controls carried by national tax authorities and administrative cooperation between Member States. ${ }^{64}$

For a fuller picture of how VAT should be levied in intra-Community distance sales of goods as from 1 January 2021, it is also important to take into consideration the new rules on the VAT liability of online platforms that is taxable persons, facilitating through the use of an electronic interface of such supplies. These rules are discussed in Sect. 4.

\subsection{Importation of goods and "distance sale of goods imported from third territories or third countries"}

One of the core issues which the e-commerce VAT package aimed at addressing, has been distortion of competition caused by the VAT exemption for the importation of small consignments from suppliers in third countries. ${ }^{65}$ In accordance with Article 143(b) and (c) of the VAT Directive, the scope of which is further determined by Directive 2009/132/EC, ${ }^{66}$ final importation of goods of negligible value not exceeding a total value of EUR 10 to EUR $22^{67}$ shall be exempt. Such an exemption is justified when the administrative costs of the collection of tax on such goods surpass the VAT due. However, in the context of the rapidly expanding volume of this type of transactions in e-commerce economy, ${ }^{68}$ the distortions caused by the exemption are far from negligible. The exemption as such has been creating unequal treatment between, on the one hand, offshore suppliers of low value goods, and suppliers operating within EU borders. Furthermore the exemption has been used by fraudsters who have been

\footnotetext{
${ }^{62}$ See further Sect. 3.4 .

${ }^{63}$ See also Lejeune, Herbain [15].

${ }^{64}$ See also Lamensch [13] and European Court of Auditors, Special Report no 12/2109, E-commerce: many of the challenges of collecting VAT and customs duties remain to be resolved, available at http://publications.europa.eu/webpub/eca/special-reports/e-commerce-12-2019/en/\#chapter0 [8].

${ }^{65}$ E-commerce VAT package Impact Assessment, p. 15.

${ }^{66}$ Council Directive 2009/132/EC of 19 October 2009 determining the scope of Article 143(b) and (c) of Directive 2006/112/EC as regards exemption from value added tax on the final importation of certain goods. [2009] OJ L 292/5.

${ }^{67}$ Amount to be decided by each Member State.

${ }^{68}$ According to the Commission's estimates from 2015, approximately 150 million parcels below EUR 22 are imported annually into the European Union and that number is growing by minimum $15 \%$ per year, making the effective control by customs and tax authorities virtually impossible.
} 
undervaluing or declaring goods imported as gifts in order to attract the exemption, thus causing significant loss of revenue by the Member States. ${ }^{69}$ As of from 2021 , the small value consignment exemption will be abolished which means that VAT will be due on all importations of goods, irrespective of their value.

To compensate for the increase in volume of inbound transactions on which VAT will be due, and to simplify the collection of VAT on a significant share of imported goods, for those goods which are below the customs exemption threshold, a special regime for payment of VAT has been introduced, which envisages, first of all, the creation of a new category of taxable transactions, namely distance sales of goods imported from third territories or third countries, and secondly the introduction of a new special scheme (an import scheme) for a share of transactions falling within that category in Sect. 4 of Chap. 6 of Title XII of the VAT Directive. ${ }^{70}$

The definition of distance sales of goods imported from third territories or third countries, includes the same elements as the definition of intra-Community distance sales of goods, with the difference being, that in case of the former, the goods must be dispatched or transported from outside the territory of the European Union. ${ }^{71}$ The fact that a transaction falls in that category does not disqualify it as importation of goods within the meaning of Article 30 of the VAT Directive. In other words, one transaction can constitute both the importation of goods and the distance sale of goods imported from third territories and third countries. VAT shall nevertheless be collected on that transaction only once, either on the importation of the goods or on distance sales. The fate of the transaction and the way in which VAT will be collected depends on whether the special import scheme is applicable (in which case the transaction will be taxed as a distance sale of imported goods, and the importation will be exempt) or not (in which case the transaction will be taxed as the importation of goods, and the place of supply of distance sale of goods will be outside the territorial scope of application of the VAT Directive). The new rules governing the distance sales of goods imported from third territories or third countries are presented in more detail further below.

The place of supply of distance sales of imported goods is to be determined in accordance with the new Article 33(b) and (c). Where the goods are imported into a Member State other than that in which dispatch or transport of the goods to the customer ends, the place of supply will be deemed to be the place where the goods are located at the time when the dispatch or transport of the goods to the customer ends. ${ }^{72}$ Where the goods' final destination is the Member State of importation, the place of supply of distance sales of goods will be deemed to be that Member State provided that the VAT on those goods is to be declared under the newly-introduced

\footnotetext{
${ }^{69}$ According to the Commission, EUR 1 billion of tax revenue loss is suffered due to the small consignment importation exemption and EUR 4 billion due to abuses.

${ }^{70}$ That new special scheme is introduced by Article 2(30) of the Council Directive (EU) 2017/2455.

${ }^{71}$ See the new Article 14(4)(2) of the VAT Directive, introduced by Article 2(1) of the Council Directive (EU) $2017 / 2455$.

${ }^{72}$ The new Article 33(b) introduced by Article 2(3) of the Council Directive (EU) 2017/2455 corresponds in essence with the current Article 33(2) of the VAT Directive, which deems the imported goods, whose transport ends in another Member State that the Member State of importation, to be dispatched or transported from the Member State of importation.
} 
import scheme. ${ }^{73}$ On the contrary, where VAT is not to be declared through that special scheme, the place of supply of distance sales of goods shall be established based on Article 32 of the VAT Directive, and thus be in the state or territory where the transport begins, falling outside the territorial scope of application of the VAT Directive.

To avoid double taxation of distance sales of imported goods which coincide with the importation of goods, an exemption on the importation of goods declared under the special scheme has been introduced. ${ }^{74}$ The exemption is conditional upon provision of the individual VAT identification number for the application of the special scheme of the supplier or the intermediary acting on his behalf to the competent customs office in the Member State of importation.

As has already been mentioned, whether or not the special scheme is applicable will be of decisive importance for the actual VAT treatment of the imported goods. The special scheme is available for distance sales of goods imported from third territories or third countries, where such goods are not subject to excise duties, and are in consignments of an intrinsic value not exceeding EUR 150 (the customs exemption threshold). ${ }^{75}$ Furthermore, to be used by a person not established in the European Union, that person has either to be represented by an intermediary established in the European Union, or to be carrying out distance sales of goods from a third country with which the Union has concluded an agreement on mutual assistance and to be established in that country. ${ }^{76}$ Where the scheme is used, the supplier or the intermediary must register for the purposes of that scheme in a Member State, charge VAT to the customer at the time when the payment is accepted ${ }^{77}$ and pay and declare VAT monthly through the so called "import OSS" or "IOSS". 78

Making use of the special scheme is optional for the eligible taxable persons. Where a supplier chooses not to use the OSS, the transaction will be taxed in the European Union as the importation of goods, either based on rules applicable to importation of goods currently in force, or based on the newly introduced "special arrangements for declaration and payment of import VAT". ${ }^{79}$ Where the latter option is used, the person presenting the goods to customs (postal operators and couriers) on behalf of the person to whom the goods are destined (the customer) ${ }^{80}$ is required to

\footnotetext{
${ }^{73}$ The new Article 33(c) introduced by Article 2(3) of the Council Directive (EU) 2017/2455.

${ }^{74}$ Article 143(1)(ca) of the VAT Directive introduced by Article 2(9) of the Council Directive (EU) $2017 / 2455$.

${ }^{75}$ Article 3691 of the VAT Directive.

${ }^{76}$ Article $369 \mathrm{~m}$ of the VAT Directive.

${ }^{77}$ Article 369n of the VAT Directive. See also the proposed new Article 61b of the VAT Implementing Regulation further clarifying the concept of "the time when the payment is accepted": European Commission, Proposal for a Council Implementing Regulation amending Implementing Regulation (EU) No. 282/2011 as regards supplies of goods or services facilitated by electronic interfaces and the special schemes for taxable persons supplying services to non-taxable persons, making distance sales of goods and certain domestic supplies of goods from 11 December 2018, COM(2018) 821 final, Article 1(5).

${ }^{78}$ Article 369 s of the VAT Directive. A taxable person registered for the special scheme must submit an electronic report each month, irrespective of whether the transactions falling in the scope of that scheme have been carried out.

${ }^{79}$ See Article $369 y$ and the following of the VAT Directive.

${ }^{80}$ As regards who is liable for the payment of the tax, see Article $369 \mathrm{z}(1)$ (a) of the VAT Directive.
} 
collect from the customer, report electronically in a monthly declaration ${ }^{81}$ and remit the tax due. ${ }^{82}$ The new provisions also envisage a record-keeping obligation for persons making use of this special arrangement. ${ }^{83}$ From the perspective of the customer the disadvantage of using the special arrangement is that Member States may provide that only the standard VAT rate is applicable when that arrangement is used, even when the imported goods would have otherwise qualified for a reduced rate. ${ }^{84}$

The purchase of goods by end-customers in European Union from suppliers established outside the European Union has been one of the most problematic issues for the effective collection of VAT. ${ }^{85}$ The problem however goes far beyond the existence of the low value consignment exemption and should be rather associated with lack of compliance and fraud by taxable persons remaining beyond the enforcement jurisdiction of Member States' tax authorities. That problem is not likely to be fixed by the mere removal of the exemption, and the provision of OSS and a special arrangement for payment of VAT on such transactions - the key being rather an effective monitoring mechanism and stringent controls. ${ }^{86}$

Furthermore, one of the reasons for non-compliance has been claimed to follow from the complexity of the existing rules on the importation of goods. ${ }^{87}$ It should be noted that the new rules, which are applicable from 2021, instead of clarifying the existing rules on importation, add to the complexity by providing several ways in which VAT can be collected on importation by different actors, depending on the intrinsic value of the goods but also on the choice of the supplier, and-as seems to follow from the provisions on the "special arrangement" - on the choice by the persons presenting the goods to customs on behalf of the end-customer. ${ }^{88}$

The new provisions introduce new possibilities for avoidance and fraud, for instance making use of the exemption on importation without the actual payment of VAT through the OSS. ${ }^{89}$ An efficient tool to combat fraud should not only allow the verification of whether VAT has been declared and paid but also whether the values declared have been correct.

The Commission is committed to further address VAT fraud in the e-commerce sector. On 12 December 2018 the Commission has presented proposals to that

\footnotetext{
${ }^{81}$ Article $369 \mathrm{zb}$ of the VAT Directive. The adopted provisions stipulate that the global payment of import VAT must be paid to customs by the end of the month following that of importation. The Commission has proposed to amend the provisions so that the deadline for payment of VAT within the special arrangements is aligned to the deadline laid down for a global payment of the customs debt. See COM(2018) 819 final.

${ }^{82}$ Article $369 y$ of the VAT Directive.

${ }^{83}$ Article $369 \mathrm{zb}(3)$ of the VAT Directive.

${ }^{84}$ Article $369 \mathrm{za}$ of the VAT Directive.

${ }^{85}$ It has been also recognised as one of the main challenges related to digital economy by the 2015 BEPS Action 1 Report (OECD, Addressing the Tax Challenges of the Digital Economy, Action 1-2015 Final Report [17]) [8].

${ }^{86}$ See also European Court of Auditors, Special Report no 12/2109, "E-commerce: many of the challenges of collecting VAT and customs duties remain to be resolved", available at http://publications.europa.eu/ webpub/eca/special-reports/e-commerce-12-2019/en/\#chapter0.

${ }^{87}$ E-commerce VAT package, Impact Assessment, p. 14.

${ }^{88}$ Article $369 y$ of the VAT Directive.

${ }^{89}$ Lamensch, Adoption of the E-Commerce VAT Package ... [10].
} 
end, ${ }^{90}$ complementing the e-commerce VAT package in order to "pave the ground for a smooth application of the new measures introduced". 91 The proposals envisage strengthening the cooperation between tax authorities and payment service providers $^{92}$ and providing for efficient tools to identify fraudsters even outside the borders of the European Union. ${ }^{93}$

The enacted legislation partly addresses the problems of non-compliance by offshore providers of goods through new obligations being imposed on the electronic interfaces facilitating distance sales, which will participate in collection of VAT on the supplies in which they intermediate. These provisions are further discussed in Sect. 4.

\section{Electronic interfaces facilitating distance sales}

\subsection{Platforms' liability for collection of VAT}

One of the important novelties to be implemented by 1 January 2021, is the special treatment of certain supplies of goods to end customers where such supplies are facilitated by online platforms, referred to in the provisions of the VAT Directive generally as electronic interfaces, such as marketplaces, platforms, portals or similar means. ${ }^{94}$ The new Article 14a of the VAT Directive, ${ }^{95}$ adopted by the Council despite the fact that it had not been included in the proposal by the Commission, envisages platforms' liability for the collection of VAT in respect of certain supplies of goods. Additional issues related to platforms, which have not been resolved in the adopted provisions, have been subject to a new proposal by the Commission from 11 December $2018 .^{96}$

In the light of Article 14a, there are two types of situations, which will trigger platforms' liability. The first one is distance sales of goods imported from third territories or third countries in consignments of an intrinsic value not exceeding EUR

\footnotetext{
${ }^{90}$ European Commission, Proposal for a Council Directive amending Directive 2006/112/EC as regards introducing certain requirements for payment service providers from 12 December 2018, COM(2018) 812 final and Proposal for a Council Regulation amending Regulation (EU) No. 904/2010 as regards measures to strengthen administrative cooperation in order to combat VAT fraud, from 12 December 2018, $\operatorname{COM}(2018) 813$ final.

${ }^{91} \mathrm{COM}(2018) 812$ final, explanatory memorandum.

${ }^{92}$ As reported by the Commission, payment services intermediaries participated in more than $90 \%$ of online purchases in recent years. See ibid.

${ }^{93}$ Ibid.

${ }^{94}$ See also the description of the role of multi-sided platforms such as e-commerce marketplaces by the OECD in OECD, The role of digital platforms in the collection of VAT/GST on online sales, as presented for consideration at the fifth meeting of the Global Forum on VAT March 2019, p. 14, available at http://www.oecd.org/ctp/global-tax-community-welcomes-new-measures-to-enlist-online-marketplacesin-the-collection-of-vat-gst-in-e-com [18].

${ }^{95}$ See Article 2(2) of the Council Directive (EU) 2017/2455.

${ }^{96} \operatorname{COM}(2018) 819$ final and $\operatorname{COM}(2018) 821$ final. At the moment of writing of the article the proposals have formally not been adopted. On 12 March 2019 the Council reached a general approach on the proposals. Final adoption of the new rules will be possible after the European parliament delivers a consultative opinion.
} 
150 , and the other is a B2C supply of goods within the European Union (either within one Member State or cross border) by a supplier not established within the European Union. In both scenarios, where an electronic interface facilitates such a supply, the platform shall be deemed to have received and supplied those goods itself. In other words, a fiction of two consecutive supplies of goods, one between the actual supplier and the platform and the second one between the platform and the end-consumer, is created.

Additional provisions applicable to platforms with effect from 2021 include special rules as to chargeable events and record keeping obligations. Pursuant to the new Article 66a, the chargeable event and chargeability of VAT in the event of deemed supplies by platforms occurs at the time when the payment has been accepted. ${ }^{97}$

Article 242a obliges the platforms that facilitate the supply of goods or services to a non-taxable person within the European Union to keep records of the supplies and make them available electronically on the request of the Member State in order to enable the tax authorities to verify that VAT has been accounted for correctly. ${ }^{98}$ The wording of Article 242a indicates that the record-keeping obligation is applicable not only to platforms liable for VAT in accordance with Article 14a, but more broadly, to all platforms facilitating supplies of goods and services. The Commission has proposed to limit the scope of the application of that provision to platforms falling within the scope of Article 14a and platforms in the circumstances covered by Article 9a of the VAT Implementing Regulation, that is when the platforms taking part in supplies of electronically supplied services are deemed to be acting in their own name and on behalf of the principal supplier and thus fulfilling the conditions of Article 28 of the VAT Directive. ${ }^{99}$ The Commission's proposal includes also further clarification to be included in the VAT Implementing Regulation as to the type of information to be kept in the records of platforms. ${ }^{100}$

The rationale behind the involvement of platforms in collecting VAT on such supplies of goods rest on the role of platforms in the e-commerce economy. According to the OECD, approximately $67 \%$ of e-commerce supplies of goods are made via digital platforms, and the vast majority of these only through the three biggest platforms. ${ }^{101}$ Streamlining the collection of VAT through such marketplaces significantly facilitates the enforcement of compliance and the effective collection of VAT. Several tax jurisdictions have contemplated and adopted provisions shifting part of the col-

\footnotetext{
${ }^{97}$ Although in the legislation as adopted, the concept of the moment of the acceptance of the payment has not been further defined, in the recent proposal of further amendments to the VAT Implementing Regulation, the Commission has included specific provisions setting conditions for determining when payment is accepted. The proposed new Article 41a of the VAT Implementing Regulation specifies that the moment of the acceptance of payment is the time when the payment confirmation, the payment authorisation message or a commitment for payment from the customer is received by or on behalf of the supplier selling goods through the electronic interface regardless of when the actual payment of money is made. See COM(2018) 821 final, Article 1(3).

${ }^{98}$ Compare with OECD, (2019), Chap. 3 "Other roles or digital platforms to support the collection of VAT/GST on online sales".

${ }^{99}$ See the proposed Article 54c of the VAT Implementing Regulation, in $\operatorname{COM}(2018) 821$ final, Article $1(4)$.

${ }^{100}$ Ibid.

${ }^{101}$ OECD, 2019.
} 
lection obligation or liability onto such actors, including Australia. ${ }^{102}$ Two of the Member States of the European Union, namely United Kingdom ${ }^{103}$ and Germany have already imposed in their domestic laws certain obligations on online platforms, including joint and several liability and a record-keeping obligation. ${ }^{104}$

The solution adopted in the European Union corresponds with what has been referred to be OECD as a "full VAT/GST liability regime" and has been considered by the latter as one of the possible regimes for imposing liability on digital platforms with a key policy objective being to reduce the costs and risks for tax authorities of administering, policing and collecting VAT. ${ }^{105}$

In the following sections Article 14a will be further analysed in order to clarify whether and with what consequences it should apply to transactions in which platforms are involved and to identify potential interpretative challenges.

\subsection{The scope}

One of the fundamental questions in relation to application of Article 14a is its scope of application. The provisions of the e-commerce VAT package did not, as adopted, include any definition of the concept of "facilitate" and therefore it has not been clear which platforms will have to face the new obligations. The scope of that concept has been discussed by representatives from the Member States in the framework of the Group on the future of VAT. ${ }^{106}$ It has been agreed that the scope of the term "facilitate" is intended to be broader than the similar term "takes part in the supply" used in Article 9a of the VAT Implementing Regulation in relation to platforms being deemed to provide electronically supplied services in their own name. The Commission has proposed to clarify the scope of Article 14a by defining "facilitate" as "use of an electronic interface to allow a customer and a supplier, selling goods through the electronic interface, to enter into contact which results in a supply of goods through that electronic interface to that customer." ${ }^{107}$ Furthermore, the proposed Article 5b of the VAT Implementing Regulation stipulates that a platform does not facilitate a supply of goods where it "does not set, either directly or indirectly, the general terms under which the supply of goods is made", "is not, either directly or indirectly, involved in charging the customer in respect of the payment made" and "is not, either directly or indirectly, involved in the ordering or delivery of the goods." It seems that for the platform not to fall within the scope of Article 14a, all of these conditions need to be fulfilled cumulatively. Therefore, is it is sufficient that the platform sets

\footnotetext{
${ }^{102}$ Ibid.

103 At the time of writing of this article, the United Kingdom is still a Member State of the European Union.

${ }^{104}$ See for more details Bal [1].

105 Ibid., Sect. 2.2.

${ }^{106}$ Informal Commission expert groups composed of representatives of national tax administrations provide the Commission a forum for consulting VAT experts from Member States on pre-legislative initiatives. See for instance Group on the future of VAT, GFV No. 072 REV 2 from 23rd meeting [4].

${ }^{107}$ The proposed Article 5b of the VAT Implementing Regulation, COM(2018) 821 final, Article 1(1)(b). See also the proposed Article 54b of the VAT Implementing Regulation, COM(2018) 821 final, Article 1(4).
} 
the rules or is involved in the ordering or delivery of the goods to the customer for the deeming provision to apply. The proposal also envisages that Article 14a not apply to platforms that only provide "the processing of payments in relation to the supply of goods, or "the listing or advertising of goods", or "the redirecting or transferring of customers to other electronic interfaces where goods are offered for sale, without any further intervention in the supply."108

Article 14a is applicable also to platforms not established in the European Union, the criteria delimiting the scope of application being the type of transaction (and thus the location and intrinsic value of goods) ${ }^{109}$ or the type of transaction and the place of establishment of the supplier. ${ }^{110}$ Notably, the provision does not apply to $\mathrm{C} 2 \mathrm{C}$ transactions and to services facilitated by platforms. ${ }^{111}$

\subsection{The commercial and economic reality of the transaction?}

It should be noted that Article 14a is applicable when the conditions for a platform to be considered as facilitating the supply are fulfilled, without the need to further establish whether the platform is acting in its own name. In other words, the provision covers also situations where the platform is acting in the name and on behalf of the supplier. Another provision in the VAT Directive creating a legal fiction of the existence of a supply of goods for the purposes of VAT, in commercial transactions involving three parties, is Article 14(2)(c), concerning a transfer of goods pursuant to a contract under which commission is payable on purchase or sale. Article 14(2)(c) stipulates that in the framework of such a contract, there are two consecutive supplies of goods for the purposes on VAT. The first supply takes place between the principal supplier and the intermediary and the second supply between the intermediary and the purchaser, in spite of the fact that a commission (which could be also seen as consideration for a supply of a service of intermediation) is paid. A commission contract is a contract under which the intermediary acts in his own name, yet on behalf of the principal purchaser or seller. The intermediary acts as an undisclosed agent, where the actual identity of the seller or the purchaser is not disclosed to the other party. ${ }^{112}$ Article 14(2)(c) ensures that the VAT treatment follows the commercial and legal characteristics of such transaction, where the commissionaire does not have to reveal the identity of the principal for the purposes of invoicing.

In contrast, in the case of the new Article 14a, the deeming provision may create certain complications where the platform is not acting in its own name. For instance, where the price is paid directly to the principal supplier, and it is a supplier who handles the delivery and returns of the goods, the VAT treatment will depart from the

\footnotetext{
${ }^{108}$ Ibid. Compare OECD (2019), Sect. 2.2.2.

${ }^{109}$ In case of Article 14a(1).

${ }^{110}$ In case of Article $14 \mathrm{a}(2)$.

${ }^{111}$ The platforms play an important role in facilitating the supply of services in the sharing economy. According to OECD tax administrations are interested in further exploring of the role of platforms for tax purposes also for that type of transaction, the specific characteristics of the sharing economy require separate, special consideration. See OECD (2019), Sect. 1.3.3. For an analysis of VAT treatment of the sharing economy, see for instance Beretta [2].

${ }^{112}$ Terra, Kajus [20], Sect. 10.2.1.4.
} 
commercial reality of the transaction in question. The deeming provision presupposes that the platform issue an invoice for the deemed supply of goods it is effecting, and collect and remit VAT which becomes chargeable at the moment of acceptance of the payment, even where the platform does not receive such payment. ${ }^{113}$ The platform may be also faced with an obligation to repay the collected VAT when the goods are returned. ${ }^{114}$ The platform, not acting in its own name, will not assume the rights and obligations steaming from the sale contract, such as for instance guarantee related duties. Nevertheless, as, for the purposes of VAT, the platform is deemed to be a supplier, it is required to comply with various VAT related obligation. That will necessarily compromise the certainty and simplicity ${ }^{115}$ of the provisions, will create practical complications, impose additional administrative burden on the electronic platforms, and increase the risk of fraud, especially where the deemed supply rules apply in conjunction with the new provisions on distance sales of goods imported from third territories or third countries. ${ }^{116}$

\subsection{Deemed supply or deemed supply with transport?}

Another interpretative difficulty stemming from Article 14a is the fact that by introducing deemed supplies of goods between the three persons concerned, the provision in fact creates, through a legal fiction, chain transactions. Such transactions are inevitably linked to the issue of determining to which of the two transactions transport should be assigned. ${ }^{117}$ In the end, the character of a transaction (whether or not it is a distance sale and consequently whether OSS can be used) as well as the place of supply depends on whether a transaction is a supply of goods with transport. Member States, in the framework of discussions in the Group on the Future of VAT, agreed that for the purposes of application of Article 14a, transport should be ascribed to the transaction between the platform and the end consumer and this has been reflected in the Commission's proposal to introduce Article $36 \mathrm{~b}$ into the VAT Directive. ${ }^{118}$ Without that additional provision, the transaction to which the transport should be ascribed would have to be determined based on the existing case law of the European Court of Justice, and would in many situations deprive Article 14a of its intended outcome. For instance, were transport to be assigned to the transaction between the principal supplier and the platform, the subsequent supply between the platform and final customer would have to be regarded as a local supply. None of the supplies would fulfill the conditions of a distance sales of goods imported through third territories or third countries. In the light of the provisions which have been currently

${ }^{113}$ In that situation, the platform will need to recover the VAT component from the underlying supplier. See also OECD (2019), p. 25.

${ }^{114}$ Lamensch, Rendering Platforms Liable ... [11].

${ }^{115}$ See OECD, 1998.

${ }^{116}$ See also Lamensch, Rendering Platforms Liable ... [11].

${ }^{117}$ See Court of Justice of the European Union (CJEU) judgments in for instance case C-245/04 EMAG, EU:C:2006:232; C-430/09 Euro Tyre, EU:C:2010:786; C-587/10 VSTR, EU:C:2012:592; C-580/16 Hans Buhler, EU:C:2018:261; C-386/16 Toridas, EU:C:2017:599.

${ }^{118}$ See COM(2018) 819 final, Article 1(1). 
adopted, it would not be possible for the platform to declare and pay VAT through OSS, which-especially in the case of platforms not established in the European Union-would increase the risk of non-compliance. ${ }^{119}$

\subsection{The treatment of the business to business (B2B) supply}

From the perspective of the rationale for the provisions on platforms' liability for collection of VAT on e-commerce transactions, the treatment of the B2C transaction, between the platform and the consumer, as a deemed supply is crucial. The analogous treatment of the B2B transaction between the principal supplier and the platform is a logical consequence motivated by the objective of maintaining normal operation of the system where VAT is collected at every stage of the production-distribution chain. Nevertheless, in practice, it implies several disadvantages from the perspective of both platforms and tax administrations. For platforms, the necessity to pay VAT on the deemed supply of goods to them implies a cash flow disadvantage, especially where the place of supply is in a jurisdiction other than the one in which they are established. In case of suppliers not established in the European Union, where the place of supply is within one of the European Union's tax jurisdictions, ${ }^{120}$ the collection of VAT on that supply depends on the compliance by the non-established supplier, and thus the risk of VAT revenue loss is not eliminated. To address those disadvantages, the Commission proposed to apply an exemption with a right to deduction to the first transaction in the chain of transactions covered by Article $14 \mathrm{a}(2){ }^{121}$

It should be added that, where Article $14 \mathrm{a}(1)$ is applicable and under an assumption that the transport is deemed to be ascribed to the second supply of goods (B2C supply), the place of supply of goods to a platform is outside the territorial scope of application of the VAT Directive, and its treatment will depend on the solution adopted in a given tax jurisdiction.

\subsection{Further issues addressed in the proposals}

Several further problematic issues relating to the new provisions applicable to platforms have been identified since the e-commerce VAT package was adopted. The Commission proposed further amendments intended to reduce certain administrative burdens and limit the liability of the platforms. These included the introduction of a provision in the VAT Implementing Regulation stipulating that platforms should not be held liable for the payment of any amount of VAT in excess of the VAT which is declared and paid on sales made through the electronic interfaces where three conditions are met cumulatively. ${ }^{122}$ First of all, the platform must be dependent on information provided by suppliers or by other third parties. Secondly, that information

\footnotetext{
${ }^{119}$ Note however, that the Commission has proposed the extension of OSS also to domestic supplies of electronic interfaces covered by Article 14a, where the platforms are established within the European Union: See COM(2018) 819 final, Article 1(6)-(11).

${ }^{120}$ In circumstances of Article 14a(2).

${ }^{121}$ See Article 136a and 169(b) of the VAT Directive proposed in Article 1(2) and (3) of COM(2018) 819 final.

${ }^{122}$ See Article 5c(1) of the Implementing Regulation proposed in Article 1(1)(b) of $\operatorname{COM}(2018) 821$ final.
} 
must be erroneous and finally, the platform can demonstrate that it did not and could not reasonably know that this information was incorrect. It remains unclear in which circumstances a platform should be considered to be "dependent on information provided by suppliers or by other third parties". Where that condition is not fulfilled, the platform will be held liable even if it could demonstrate good faith.

Furthermore, to facilitate the application of the new rules, without imposing the burden of proof regarding the status of the supplier and the consumer, a legal presumption was introduced pursuant to which suppliers selling goods through the platform will be presumed to be taxable persons while the customers are presumed to be non-taxable persons unless he platform has information to the contrary. ${ }^{123}$ It is not clear what level of scrutiny is required from the platforms in order to rebut that presumption.

\section{Conclusions}

Taxation of e-commerce is currently high on the political agenda, both in the European Union and beyond, with significant efforts being put into creating rules ensuring undistorted functioning of the internal market and effective taxation of the digital economy without creating barriers for online trade. The e-commerce VAT package's introduction of a significant number of changes to the applicable rules is an important attempt in line with those objectives. In this article, the core of the new rules has been outlined and analysed.

The purpose of the package was to level the playing field for businesses, reduce the complexity of the provisions, decrease the compliance burden and provide for more fraud-resistant rules. While it could be concluded that several of the new provisions will indeed contribute to achieving these objectives, others seem to go against them.

On the positive side as regards the achievement of a level playing field and the minimisation of distortions of competition, credit should be given for the removal of the exemption for the importation of low value consignments and the lowering of the threshold for taxation at destination on distance sales of goods. On the other hand, the introduction of a threshold for taxation at destination for B2C TBE services, as well as the differing treatment of businesses established and not established in the European Union in relation to many of the new rules runs counter to those objectives.

Reduction of complexity has been sought via simplifications for Union suppliers of TBE services, the introduction of a Union-wide threshold for distance sales and via significant extension and amendments to MOSS. However, the number of the schemes available, their different personal scope, as well as the new rules on payment of import VAT and on a platform's liability are likely to introduce a lot of new complexities and interpretative challenges both for businesses and for tax and custom authorities. $^{124}$

\footnotetext{
${ }^{123}$ See Article 5c(2) of the Implementing Regulation proposed in Article 1(1)(b) of COM(2018) 821 final.

${ }^{124}$ It should be added that the amendments introduced by the e-commerce VAT package have not been the only new rules affecting the European Union VAT system in recent months. As of from 1 January 2019, the new provisions on vouchers have also been applicable. The provisions on a transfer of single purpose voucher by a taxable person acting in the name of another taxable person seem to clash with the new Article $14 \mathrm{a}$
} 
The weakest part of the new rules seems to be the lack of resistance they display to fraud. The rules adopted do not provide for measures allowing for the enforcement of compliance by non-Union suppliers and do not reduce the risk of fraudulent behaviour such as under-reporting and undervaluation so as to circumvent the rules. The risk of abuse in relation to the new rules seems to be especially significant on distance sales of goods imported from third territories and third countries.

The Commission and the Member States have not rested on their laurels and are continuing work on further amendments and tools which should hopefully allow the more successful attainment of the pursued goals. It will be interesting to see to what extent the new tools for fighting VAT fraud in the digital context will use new technologies, big data analysis and automation, the potential of which seems not to have been sufficiently explored by the Union legislator. The most far reaching achievement, as to reliance on digitalisation, is the recently launched "transaction network analysis" (TNA), ${ }^{125}$ which is a tool for information exchange and joint processing of data, based on advanced analytics of data from various available sources with an aim of early detection of VAT fraudsters. Nevertheless, it has been submitted that the weakness of that tool is that not all the Member States actively participate in TNA and that the amount and quality of data currently reported by the Member States and available for analysis might not be sufficient for efficient functioning of the tool. In order to fully benefit from the potential of TNA is has been suggested that all Member States should collect and communicate 'real-time' data as it is currently done in Spain, Italy and Hungary. ${ }^{126}$

Acknowledgements Open access funding provided by Lund University.

Publisher's Note Springer Nature remains neutral with regard to jurisdictional claims in published maps and institutional affiliations.

Open Access This article is distributed under the terms of the Creative Commons Attribution 4.0 International License (http://creativecommons.org/licenses/by/4.0/), which permits unrestricted use, distribution, and reproduction in any medium, provided you give appropriate credit to the original author(s) and the source, provide a link to the Creative Commons license, and indicate if changes were made.

\section{References}

1. Bal, A.: Germany: New VAT Compliance Obligations for Online Platforms. EC Tax Review 28, 114119 (2019)

2. Beretta, G.: VAT and the Sharing Economy. World Tax Journal 10, 381-425 (2018)

3. Ecommerce Europe, European Ecommerce Report 2018 available at: https://www.ecommerceeurope.eu/research/ecommerce-europe-reports/

4. European Commission, Group on the future of VAT, GFV No. 072 REV 2

${ }^{125}$ On 15 May 2019. See Commission's press release available at http://europa.eu/rapid/press-release_IP19-2468_en.htm [7].

${ }^{126}$ Lamensch and Ceci, VAT fraud: Economic impact, challenges and policy issues, Study requested by the European Parliament, TAX3 Committee, PE 626.076, October 2018, available at: http://www.europarl.europa.eu/RegData/etudes/STUD/2018/626076/IPOL_STU(2018)626076_EN.pdf [14]. 
5. European Commission, Report of the Commission Expert Group on Taxation of the Digital Economy from 28.5.2014 available at https://ec.europa.eu/taxation_customs/sites/taxation/files/ resources/documents/taxation/gen_info/good_governance_matters/digital/report_digital_economy.pdf

6. European Commission, VAT for online businesses factsheet, available at https://ec.europa.eu/ taxation_customs/sites/taxation/files/vat-e-commerce-factsheet.pdf

7. European Commission, Press Release "VAT Fraud: New tool to help EU countries crack down on criminals and recoup billions", 15 May 2019, available at http://europa.eu/rapid/pressrelease_IP-19-2468_en.htm

8. European Court of Auditors, Special Report no 12/2109, E-commerce: many of the challenges of collecting VAT and customs duties remain to be resolved, available at http://publications. europa.eu/webpub/eca/special-reports/e-commerce-12-2019/en/\#chapter0

9. Herbain, C.: Value Added Tax 3.0. In: Lamensch, M., Traversa, E., van Thiel, S. (eds.) Value Added Tax and the Digital Economy. The 2015 EU rules and Broader Issues. Kluwer Law International, Alphen aan den Rijn (2016)

10. Lamensch, M.: Adoption of the E-Commerce VAT Package: The Road Ahead Is Still a Rocky One. EC Tax Review 27, 186-195 (2018)

11. Lamensch, M.: Rendering Platforms Liable to Collect and Pay VAT on B2C Imports: A Silver Bullet? International VAT Monitor 29, 48-49 (2018)

12. Lamensch, M.: Tax Assessment in a Digital Context: A Critical Analysis of the 2015 EU Rules. In: Lamensch, M., Traversa, E., van Thiel, S. (eds.) Value Added Tax and the Digital Economy. The 2015 EU rules and Broader Issues. Kluwer Law International, Alphen aan den Rijn (2016)

13. Lamensch, M.: Trust: a sustainable option for the future of the EU VAT system? Int. VAT Monit. 30 (2019), Journals IBFD

14. Lamensch, M., Ceci, E.: VAT fraud: Economic impact, challenges and policy issues, Study requested by the European Parliament, TAX3 Committee, PE 626.076, October 2018, available at http:// www.europarl.europa.eu/RegData/etudes/STUD/2018/626076/IPOL_STU(2018)626076_EN.pdf

15. Lejeune, I., Herbain, C.: Recent developments on EU VAT: VAT Digital Single Market package. British Tax Review 1-6 (2018)

16. OECD, Ottawa Taxation Framework Conditions (1998), available at https://www.oecd.org/ctp/ consumption/1923256.pdf

17. OECD, Addressing the Tax Challenges of the Digital Economy, Action 1-2015 Final Report, available at: http://www.oecd.org/tax/addressing-the-tax-challenges-of-the-digital-economy-action-12015-final-report-9789264241046-en.htm

18. OECD, The role of digital platforms in the collection of VAT/GST on online sales, as presented for consideration at the fifth meeting of the Global Forum on VAT March 2019, available at: http://www.oecd.org/ctp/global-tax-community-welcomes-new-measures-to-enlist-onlinemarketplaces-in-the-collection-of-vat-gst-in-e-com

19. Raponi, D., O'Sullivan, D.: VAT and Taxation of the Digital Economy from the Perspective of the EU Policy Maker. In: Lamensch, M., Traversa, E., van Thiel, S. (eds.) Value Added Tax and the Digital Economy. The 2015 EU rules and Broader Issues. Kluwer Law International, Alphen aan den Rijn (2016)

20. Terra, B., Kajus, J.: Introduction to European VAT (2019). IBFD Tax Research Platform

21. Terra, B.: The Ordeal of Indirect Tax Harmonisation (self-published), Hoorn (2019)

22. VAT Committee, Guidelines resulting from the 104th meeting of 4-5 June 2015, document Ctaxud.c.1(2015)4820441-876 